UDC $532.783+547$

\author{
S. A. Znoiko', N. V. Bumbina ${ }^{2}$, O. B. Akopova ${ }^{2}$, G. R. Berezina ${ }^{1}$, A. I. Smirnova ${ }^{2}$, N. V. Usol'tseva ${ }^{2}$, \\ V. E. Maizlish ${ }^{1}$, G. P. Shaposhnikov ${ }^{1}$
}

\title{
SYNTHESIS AND PROPERTIES OF SULFO AND ALKYLSULFAMOYL SUBSTITUTED PHTHALOCYANINES AND THEIR COPPER (II) COMPLEXES BEARING 1-BENZOTRIAZOLYL AND 4-CYCLOHEXYLPHENOXY GROUPS
}

\author{
${ }^{1}$ Research Institute of Macroheterocyclic Compounds, Ivanovo State University of Chemistry and Technology, \\ 7 Sheremetievsky Pr., Ivanovo, 153000, Russia. E-mail: znoykosa@yandex.ru \\ ${ }^{2}$ Nanomaterials Research Institute, Ivanovo State University, \\ 39 Ermak St., Ivanovo, 153025, Russia. E-mail: n_bumbina@mail.ru
}

New sulfo and alkylsulfamoyl substituted 2,9,16,23-tetrakis(1-benzotriazolyl)3,10,17,24-tetrakis(4cyclohexylphenoxy)phthalocyanines and their $\mathrm{Cu}(\mathrm{II})$ complexes were synthesized. Their physicochemical properties such as electronic absorption, solubility in organic solvents, thermostability and mesomorphism were investigated. It was established that introduction of sulfo group into cyclohexylphenoxy fragment of the studied phthalocyanines causes bathochromic shift of long wave band $s$ in both DMF and concentrated sulfuric acid solutions. In contrast, introduction of octadecylsulfamoyl substituentsdoes not influence the position of $Q$ band in $D M F$, but shifts this band hypsochromically. The performed synthesis revealed that introduction of bulky fragments into ortho-position with respect to the oxygen atom of aryloxy group excludes manifestation of liquid crystalline properties. While substitution by the same substituent in para-position leads to formation of mesophase. This fact can be connected with the sterical hindrance of liquid crystalline molecular packing. Thus, it was established that the presence of donor and acceptor fragments in mix-substituted phthalocyanines is important but not determining factor for their mesophase formation. The forecast data on the absence of mesomorphism of new phthalocyanine derivatives with sulfo and alkylsulfamoyl groups are in a good agreement with the experimental data, which is the evidence of the applicability of the method used to identify mesogen I non-mesogen structures for this class of compounds.

Key words: phthalocyanines, synthesis, mesomorphism, solubility, thermostability, mesomorphism prognosis.

DOI: $10.18083 / \mathrm{Appl} 1.2017 .1 .56$

\section{С. А. Знойко ${ }^{1,}$ Н. В. Бумбина ${ }^{2}$ О. Б. Акопова ${ }^{2}$, Г. Р. Березина ${ }^{1}$, А. И. Смирнова ${ }^{2}$ Н. В. Усольцева ${ }^{2}$,} В. Е. Майзлиш ${ }^{1}$, Г. П. Шапочников ${ }^{1}$

\section{СИНТЕЗ И СВОЙСТВА СУЛЬФОКИСЛОТ И АЛКИЛСУЛЬФАМОИЛ-ЗАМЕЩЕННЫХ ФТАЛОЦИАНИНОВ И ИХ КОМПЛЕКСОВ С МЕДЬЮ, СОДЕРЖАЩИХ 1-БЕНЗОТРИАЗОЛЬНЫЕ И 4-ЦИКЛОГЕКСИЛФЕНОКСИ ГРУППЫ}

\footnotetext{
${ }^{1}$ НИИ Макрогетероциклических соединений, Ивановский государственный химико-технологический университет, Шереметевский пр., 7, 153000 Иваново, Россия. E-mail: znoykosa@yandex.ru

${ }^{2}$ НИИ Наноматериалов, Ивановский государственный университет, ул. Ермака, 39, 153025 Иваново, Россия. E-mail: n_bumbina@mail.ru
}

Взаимодействием 2,9,16,23-тетра(1-бензотриазолил)-3,10,17,24-тетра(4-ичиклогексилфенокси) фталочиианина и его комплекса с медью со смесью тионилхлорида и хлорсульфоновой кислоты получень соответствующие сульфохлориды. Гидролизом сульфохлоридов синтезированы новые сульфокислоты

(c) Знойко С. А., Бумбина Н. В., Акопова О. Б., Березина Г. Р., Смирнова А. И., Усольцева Н. В., Майзлиш В. Е., Шапошников Г. П., 2017 
бензотриазолилзамещенных фоталоцианинов. Реакиией сульфохлорида 2,9,16,23-тетра(1-бензотриазолил)-3,10,17,24-тетра(4-ииклогексилфенокси)фталоцианина меди с октадециламином в ацетоне получено соответствующее октадецил октадецилсульфамоилпроизводное. Изучень спектральные свойства целевых соединений, их термическая устойчивость, растворимость в органических растворителях и мезоморфизм. Установлено, что при введении сульфогрупп в ииклогексилфенокси фрагмент исследуемых фталочианинов в спектрах поглощения наблюдается батохромный сдвиг длинноволновых полос как в ДМФА, так и в концентрированной серной кислоте. Введение октадеиилсульфамоильных заместителей не оказывает влияние на положение $Q$ полосы в ДМФА, но приводит к гипсохромному сдвигу этой полосы в концентрированной серной кислоте. Показано, что введение объемных сульфо- и алкилсульфамоил фрагментов в орто-положение по отночению к атому кислорода арилокси группы производных фталочиианина, исключает проявление мезоморфных свойств, в то время как аналогичное замещение в пара-положении приводит к формированию мезофазы. Данный факт объяснен стерическими влияниями на возможность межмолекулярного взаимодействия данных соединений, оптимального для формирования мезофаз. Проведенные исследования впервые позволили установить, что наличие донорных и акиепторных групп в смешанно-замещенных фталочианинах является важным, но не решающим фактором в проявлении ими мезоморфных свойств. Полученные по прогнозу данные об отсутствии мезофаз у новых производных фрталочиианина с сульфо- $и$ алкилсульфамоил группами находятся в хорошем согласии с экспериментом, что свидетельствует о применимости использованного метода к выявлению мезоген /немезогенных структур у подобного класса соединений.

Ключевые слова: фталочианины, синтез, мезоморфизм, растворимость, термогравиметрия, прогноз мезоморфизма.

\section{Introduction}

Study of the relationship between structure and properties of phthalocyanine derivatives and their mesomorphism is the fundamental task of physical chemistry of condensed matter.

At present time, experimental data on mesomorphism of bifunctionally substituted phthalocyanines are limited. The expansion of the number of such compounds will help to come closer to solve the problem of the dependence of liquid crystal properties on the structure of organic compound [1].

In this work, we continue investigations concerning synthesis of sulfo- and alkylsulfamoyl derivatives of aryloxy-substituted phthalocyanines [2-3]. We have previously shown that the presence of donor and acceptor substituents imparts the ability for non-mesogenic compounds to show thermotropic mesomorphism [4-7]. While the introduction of sulfo or alkylsulfamoyl fragments into para-position with respect to the oxygen atom of aryloxy group of mixsubstituted phthalocyanines does not affect the ability of these compounds to exhibit mesomorphism. Such substitution shifts the mesophase existence region to higher temperatures [3]. We have studied compounds with 1-methyl-1-phenylethyl substituents in phenyloxy groups, these are the fragments in which sulfo and sulfonamide moieties are located [3]. In contrast to the previously investigated compounds, the new target phthalocyanines 1-2, due to presence of cyclohexyl group in para-position of phenoxy groups, contain sulfo and alkylsulfamoyl groups in ortho-positions with respect to oxygen atom of phenoxy fragment (Fig. 1). Such change should significantly influence physicochemical and mesomorphic properties.

The aim of this work is the synthesis and investigation of physicochemical properties of sulfonic acids $\mathbf{1}$ and alkylsulfamoyl derivatives $\mathbf{2}$ of the mix-substituted phthalocyanines containing 1benzotriazolyl and 4-cyclohexylphenoxy fragments. 


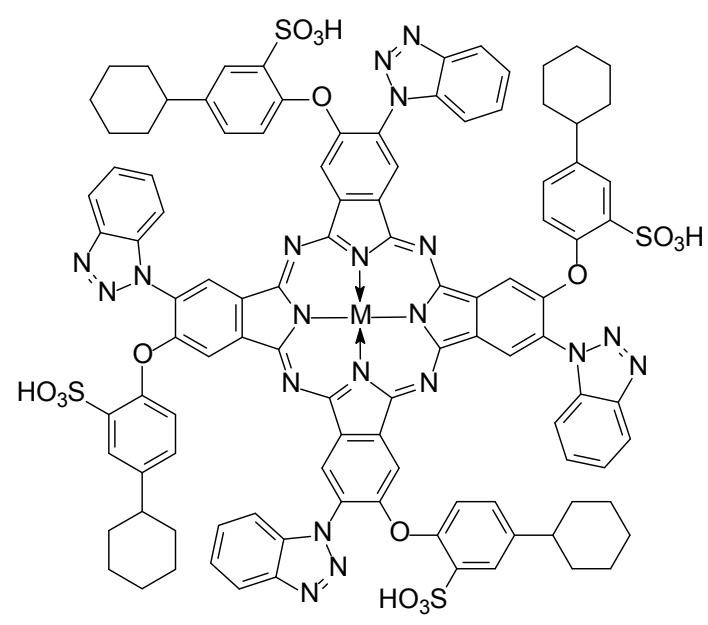

1a,b

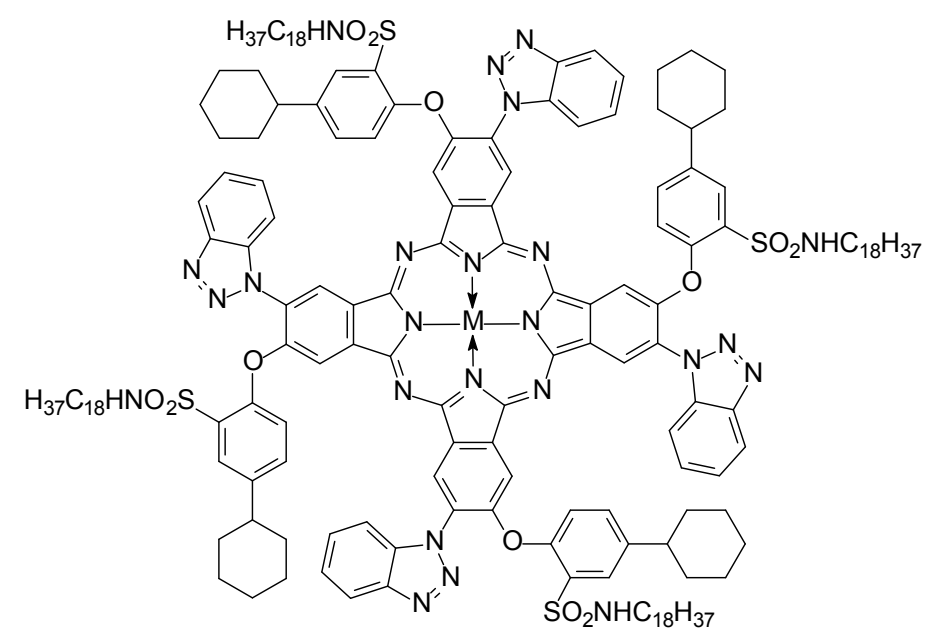

$2 a, b$

$$
\mathrm{M}=\mathrm{HH}, \mathrm{Cu}
$$

Fig. 1. Structural formulas of the studied compounds

\section{Experimental}

UV-Vis spectra of solutions of the synthesized phthalocyanines in DMF and chloroform were obtained on HITACHI U-2001 spectrophotometer at a room temperature on the spectral range of 325$900 \mathrm{~nm}$. IR spectra were recorded on Avatar 360 FTIR ESP spectrophotometer at a room temperature. ${ }^{1} \mathrm{H}$ NMR spectra of $\mathbf{1 a}, \mathbf{2} \mathbf{b}$ in $\mathrm{DMSO}\left[\mathrm{D}_{6}\right]$ and $\mathrm{CDCl}_{3}$ with TMS as internal standard were carried out on «Bruker DRX-500». Elemental analysis was performed on Flash EATM 1112 instrument. Spectral studies and elemental analysis were carried out on the equipment of the Centre for Collective Use (Ivanovo, ISUCT).

Study of solubility of 2,9,16,23-tetrakis-(1benzotriazolyl)-3,9,17,24-tetrakis(4-cyclohexylphenoxy)phthalocyanines and its copper complexes as well as their sulfonic acids was carried out according to the known procedure [8] at $298 \mathrm{~K}$ by isothermal saturation with spectrophotometric control of concentration. The systematic error in the solubility's value due to an error in the determination of the molar extinction coefficient was $5 \%$. The absorption bands with maxima at $684(\mathbf{4 a}), 685$ (4b), 683 (1a), 685 (1b) in DMF and 688 (4a), 692 (4b) in chloroform were selected as analytical bands.

Mesomorphism of sulfo- (1a, b) and octadecylsulfamoyl- (2b) phthalocyanine derivatives was studied by optical polarizing microscopy (polarizing microscope «Leitz Laborlux 12 Pol» equipped with «Mettler FP 82» heating stage, heating/cooling rate $10{ }^{\circ} \mathrm{C} / \mathrm{min}$ ). Lyotropic mesomorphism of binary systems of the studied compounds with organic solvents (DMF, DMSO, toluene, $\mathrm{CHCl}_{3}$ ) and aqueous solutions was tested by contact preparation technique on the equipment of the Nanomaterials Research Institute (Ivanovo State University).

Prediction of columnar mesomorphism for compounds 1-2 was performed using the original program CMP ChemCard [9]. The program gives the possibility to calculate the molecular parameters $(M P)$ of individual molecule and to predict whether the compound can be potential discotic mesogen. Among the advantages of this method is the simplicity of use, low cost of machine time and sufficiently high degree of reliability of the prediction (70-90\%). Prior the prediction, geometry optimization of molecular structures was performed by HyperChem software package (method $\mathrm{MM}^{+}$).

Synthesis of 2,9,16,23-tetrakis(1-benzotriazolyl)-3,10,17,24-tetrakis[4-cyclohexylphenoxy] phthalocyanine and its copper complex $(\mathbf{4 a}, \boldsymbol{b})$ was performed according to the known procedure [10]. 
Synthesis of sulfonic acids of 2,9,16,23-tetrakis(1benzotriazolyl)-3,10,17,24-tetrakis[4-cyclohexylphenoxy] phthalocyanine and its copper complex $(\mathbf{1} \boldsymbol{a}, \boldsymbol{b})$

$0.1 \mathrm{mmol}$ of compounds $\mathbf{4 a}, \mathbf{b}$ reacted with a mixture of $2 \mathrm{ml}(18 \mathrm{mmol})$ of chlorosulfonic acid and $2 \mathrm{ml}(18 \mathrm{mmol})$ of thionyl chloride at room temperature and stirred during 1 hour (in the case of metal-free phthalocyanine) or 2 hours (in the case of the corresponding copper complex). After stirring, the reaction mixture was poured onto ice and treated with sodium chloride. The precipitate was collected on a sinter and dried in a desiccator over sulfuric acid for 3 days. The resultant sulfonic chloride was extracted with acetone, the solvent was evaporated under reduced pressure. The crude product was boiled in water until it was completely dissolved. The resultant sulfonic acid was extracted with DMF, the solution was filtered through a paper filter and the solvent was evaporated. The obtained products were dark green solids, soluble in water, ammonia and aqueous alkaline solutions.

The final purification was performed by column chromatography on silica gel (M 60) using DMF as the eluent. The desired products were dried in the air at $80-90{ }^{\circ} \mathrm{C}$.

\section{2,9,16,23-Tetrakis(1-benzotriazolyl)-3,10,17,24-tetra-}

kis(2-sulfo-4-cyclohexylphenoxy)phthalocyanine (1a) was synthesized according to the main procedure from $174 \mathrm{mg}$ of compound 4a. (Yield $191 \mathrm{mg}, 92 \%$ ). Found, \%: C 62.45, H 4.33, N 14.01, S 6.41; $\mathrm{C}_{112} \mathrm{H}_{78} \mathrm{~N}_{20} \mathrm{O}_{16} \mathrm{~S}_{4}$. Requires: C 61.94, H 4.70, N 14.29, S 6.54; $v_{\max }(\mathrm{KBr}) / \mathrm{cm}^{-1}: 3418(-\mathrm{OH}), 2925,2850$ $\left(\mathrm{CH}_{2}, \mathrm{CH}_{3}\right), 1358(\mathrm{Ar}-\mathrm{O}-\mathrm{Ar}), 1330(\mathrm{~S}=\mathrm{O}$ asymm $)$, $1091(\mathrm{C}-\mathrm{S}), 1047(\mathrm{~N}=\mathrm{N}), 1024\left(\mathrm{H}_{2} \mathrm{Pc}\right), 747(\mathrm{C}-\mathrm{N}) . \delta_{\mathrm{H}}$ $\left(\left[D_{6}\right] \mathrm{DMSO}\right.$, numeration of protons is presented in Scheme 3): $9.22\left(s, 4 \mathrm{H}, \mathrm{SO}_{3} \mathrm{H}\right) ; 8.70(t, 4 \mathrm{H}, \mathrm{H} 1) ; 8.38$. $(s, 4 \mathrm{H}, \mathrm{H} 2) ; 8.29(s, 4 \mathrm{H}, \mathrm{H} 3) ; 8.20-8.10(m, 4 \mathrm{H}, \mathrm{H} 6)$; 7.83-7.90 ( $m, 4 \mathrm{H}, \mathrm{H} 4) ; 7.62(s, 4 \mathrm{H}, \mathrm{H} 8) ; 7.48-7.53$ ( $m, 4 \mathrm{H}, \mathrm{H} 5) ; 7.28(t, 4 \mathrm{H}, \mathrm{H} 9) ; 2.18(m, 4 \mathrm{H}, \mathrm{H} 10)$; 1.66 ; $1.54-1.51(m, 10 \mathrm{H}, \mathrm{H} 11,12)$.

\section{2,9,16,23-Tetrakis(1-benzotriazolyl)-3,10,17,24-tetra-} kis(2-sulfo-4-cyclohexylphenoxy)phthalocyanine copper complex (1b) was obtained according to the main procedure from $188 \mathrm{mg}$ of compound $\mathbf{4 b}$. (Yield $178 \mathrm{mg}, 80$ \%). Found, \%: C 59.98, N 13.26, H 4.30, S 6.00; $\mathrm{C}_{104} \mathrm{H}_{184} \mathrm{CuN}_{20} \mathrm{O}_{16} \mathrm{~S}_{4}$. Requires: C 60.59, $\mathrm{N} 13.59, \mathrm{H} 4.11, \mathrm{~S} 6.22 ; v_{\max }(\mathrm{KBr}) / \mathrm{cm}^{-1}: 3386(\mathrm{OH})$, 2924, 2849, $2781\left(\mathrm{CH}_{2}, \mathrm{CH}_{3}\right), 1395,1349(\mathrm{~S}=\mathrm{O}$ asymm $), 1206$ ( $\mathrm{Ar}-\mathrm{O}-\mathrm{Ar}), 1175(\mathrm{~S}=\mathrm{O}$ symm $), 1088$ $(\mathrm{C}-\mathrm{S}), 1058(\mathrm{~N}=\mathrm{N}), 745 \mathrm{C}-\mathrm{N}$.
Synthesis of 2,9,16,23-tetrakis(1-benzotriazolyl) 3, 10, 17,24-tetrakis-(2-octadecylsulfamoyl-4-cyclohexylphenoxy)phthalocyanine copper complex (2b)

Compound 4b (172 mg, $0.1 \mathrm{mmol})$ reacted with a mixture of chlorosulfonic acid $2 \mathrm{ml}(18 \mathrm{mmol})$ and thionyl chloride $2 \mathrm{ml}(18 \mathrm{mmol})$ at room temperature for 2 hours. After stirring, the reaction mixture was poured onto ice and treated with sodium chloride. The precipitate was collected on a sinter and dried in a desiccator over sulfuric acid for 3 days. The target sulfochloride was extracted with acetone. An 8-fold molar excess of octadecylamine $(0.22 \mathrm{~g}, 0.8 \mathrm{mmol})$ was added to the obtained acetone solution and the mixture was heated at $60{ }^{\circ} \mathrm{C}$ for $1-1.5$ hours. The process was controlled by the completeness of the dissolution of the reaction mixture in chloroform. After the reaction was finished, the acetone was distilled off. The desired product was extracted from the reaction mixture with chloroform. Final purification was performed by column chromatography on silica gel (M 60) using chloroform as eluent. The resulting product was dark green solid, partially soluble in DMF, highly soluble in benzene, acetone and chloroform. (Yield $233 \mathrm{mg}, 77 \%$ ). Found, \%: $\mathrm{C}$ 68.35, N 10.55, H 8.38, S 4.07; $\mathrm{C}_{176} \mathrm{H}_{232} \mathrm{CuN}_{24} \mathrm{O}_{12} \mathrm{~S}_{4}$. Requires: C 68.91, N 10.96, H 7.62, S 4.18. $v_{\max }(\mathrm{KBr}) / \mathrm{cm}^{-1}: 2920,2851\left(-\mathrm{CH}_{2},-\right.$ $\left.\mathrm{CH}_{3}\right), 1617$ (-NH $\mathrm{Nec}_{\text {sec }}$, def.), $1533\left(\mathrm{NH}_{\text {sec }}\right.$. val $), 1388$ $(\mathrm{S}=\mathrm{O}$ asymm), 1242 (Ar-O-Ar), 1088 (C-S), 1050 $(\mathrm{N}=\mathrm{N}), 746(\mathrm{C}-\mathrm{N}) ; \delta_{\mathrm{H}}\left(\mathrm{CDCl}_{3}\right.$, numeration of protons is presented in Scheme 3): $8.71(t, 4 \mathrm{H}, \mathrm{H} 1) ; 8.23(t$, $4 \mathrm{H}, \mathrm{H} 3) ; 8.12$ ( $m, 4 \mathrm{H}, \mathrm{H} 2) ; 8.03-8.05(m, 4 \mathrm{H}, \mathrm{H} 6)$; 7.87-7.77 ( $m, 4 \mathrm{H}, \mathrm{H} 4) ; 7.49(t, 4 \mathrm{H}, \mathrm{H} 5) ; 7.26(\mathrm{H} 8)$; $6.90(m, 4 \mathrm{H}, \mathrm{H} 7) ; 5.40(s, 4 \mathrm{H}, \mathrm{NH}) ; 3.15(m, 4 \mathrm{H}, \mathrm{H} 9)$; $2.98-2.91$ (H10); 1.36 (H11,12); 1.89, 1.79, 1.44 $\left(-\mathrm{CH}_{2}\right.$ in $\left.\mathrm{NHC}_{18} \mathrm{H}_{37}\right) ; 0.91\left(s, 12 \mathrm{H},-\mathrm{CH}_{3}\right)$.

\section{Results and discussions}

\section{Synthesis}

Synthesis of the target compounds was carried out starting from the corresponding bifunctionally substituted phthalocyanines $\mathbf{4 a}, \mathbf{b}$. These were obtained according to the known procedure [10] using "nitrile" method, consisting in heating the phthalonitrile 3 with copper acetate or anhydrous potassium carbonate (Scheme 1).

Then phthalocyanine derivatives $\mathbf{4 a , b}$ were separated from the reaction mixture and treated with a mixture of thionyl chloride and chlorosulfonic acid according to the method described in [2-3] (Scheme 2). 


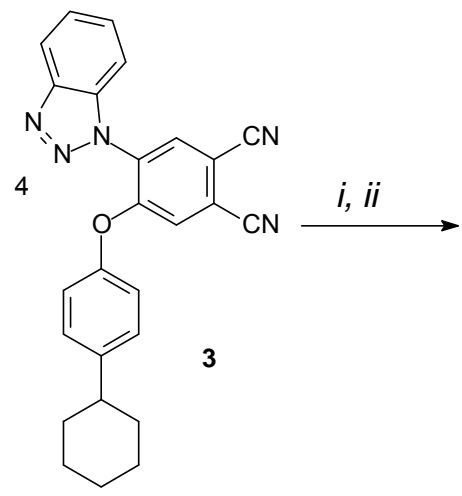

$$
\begin{aligned}
& \mathrm{M}=\mathrm{HH}(\mathrm{a}), \mathrm{Cu}(\mathrm{b}) \\
& \text { i: } \mathrm{Cu}(\mathrm{OAc})_{2}{ }^{*} 2 \mathrm{H}_{2} \mathrm{O}, 210^{\circ} \mathrm{C} \\
& \text { ii: } \mathrm{K}_{2} \mathrm{CO}_{3},\left(\mathrm{NH}_{2}\right)_{2} \mathrm{CO}, 210^{\circ} \mathrm{C}
\end{aligned}
$$

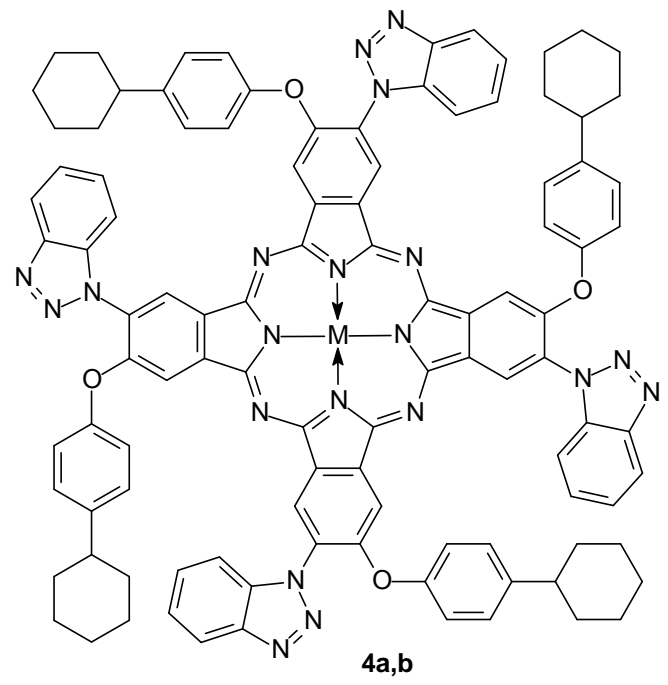

Scheme 1

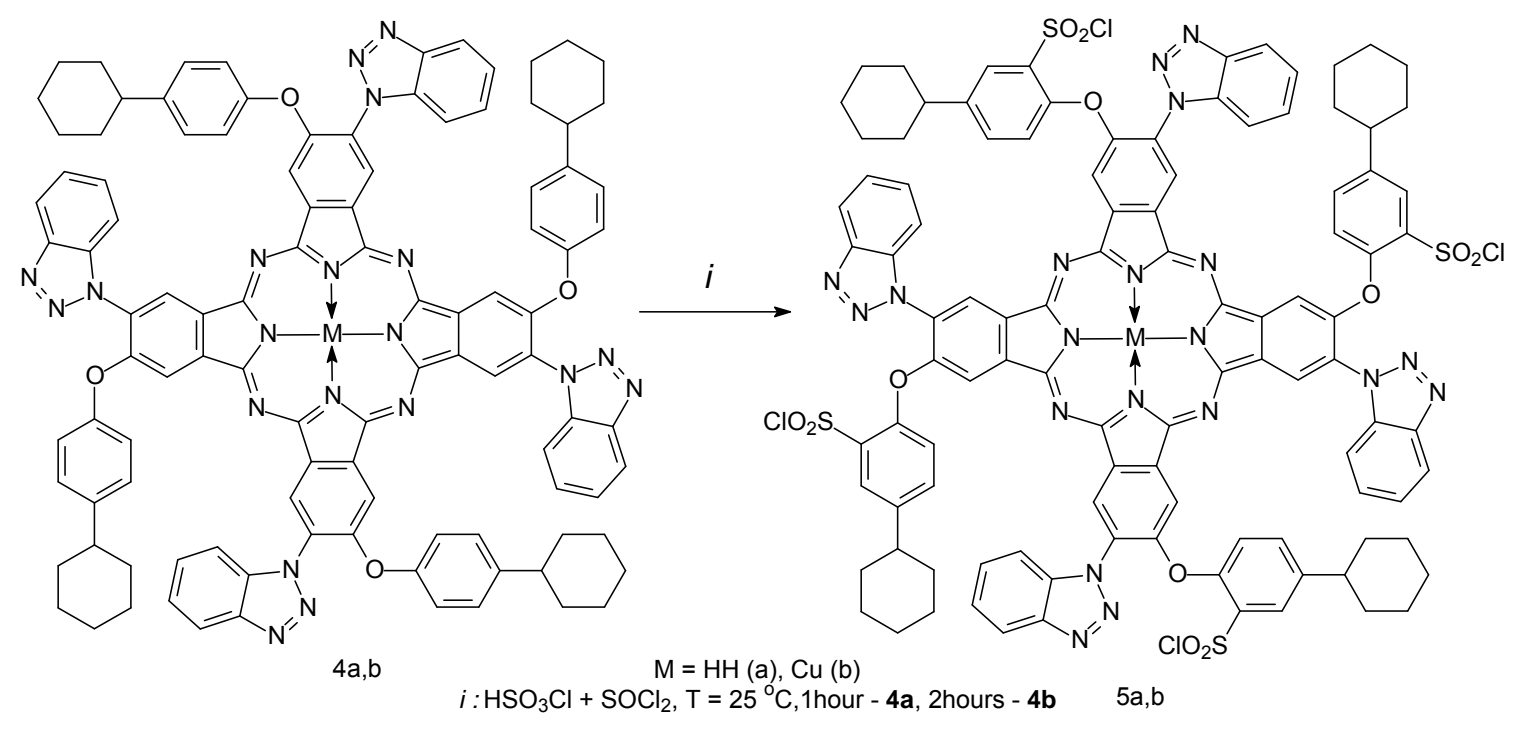

Scheme 2

The interaction time was determined by the nature of the coordination center: in the case of copper complex it was 2 hours, for metal-free phthalocyanine - 1 hour. The resulting sulfonyl chlorides $\mathbf{5 a , b}$ were isolated by pouring reaction mixture onto ice. The formed precipitate was filtered off and dried thoroughly.

For the synthesis of the corresponding sulfonic acids 1a,b the sulfonyl chlorides were extracted with acetone. The obtained solution was filtered and the acetone was distilled off. After that, the crude product was refluxed in water until its complete dissolution, and then the water was removed (Scheme 3).

For the synthesis of the octadecylsulfamoyl derivatives an 8 -fold molar excess of octadecylamine was added into the acetone extract. The resulting solution was refluxed until the test showed complete dissolution of the reaction mixture in chloroform (Scheme 3). The attempt to obtain metal-free alkyl- 
sulfamoyl phthalocyanine $\mathbf{4 a}$ by this method failed.

Identification of the synthesized compounds was performed by elemental analysis, ${ }^{1} \mathrm{H}$ NMR-, IR- and electron spectroscopy. In the ${ }^{1} \mathrm{H}$ NMR spectrum of the sulfonic acid 1a the appearance of four protons of sulfo groups at $9.07 \mathrm{ppm}$ as well as a new signal at $8.38 \mathrm{ppm}$, which was absent in the spectrum of the original phthalocyanine $\mathbf{4 a}$, were detected in the weak field region. The signal at $8.04 \mathrm{ppm}$, which was observed in the spectrum of the "parent" phthalocyanine 4a [10] and corresponded to the proton in the 2-position, was absent. This fact confirms the introduction of sulfo group into aryl fragment exactly in the ortho-position to the oxygen bridge. A similar change in the ${ }^{1} \mathrm{H}$ NMR spectrum was observed in the case of the previously studied 2,9,16,23-tetrakis(1benzotriazolyl)-3,10,17,24-tetrakis(1,6-disulfo-2-naphtoxy)phthalocyanine [2], which also contains sulfo group in the ortho-position to the oxygen bridge in the phenyloxy fragment.

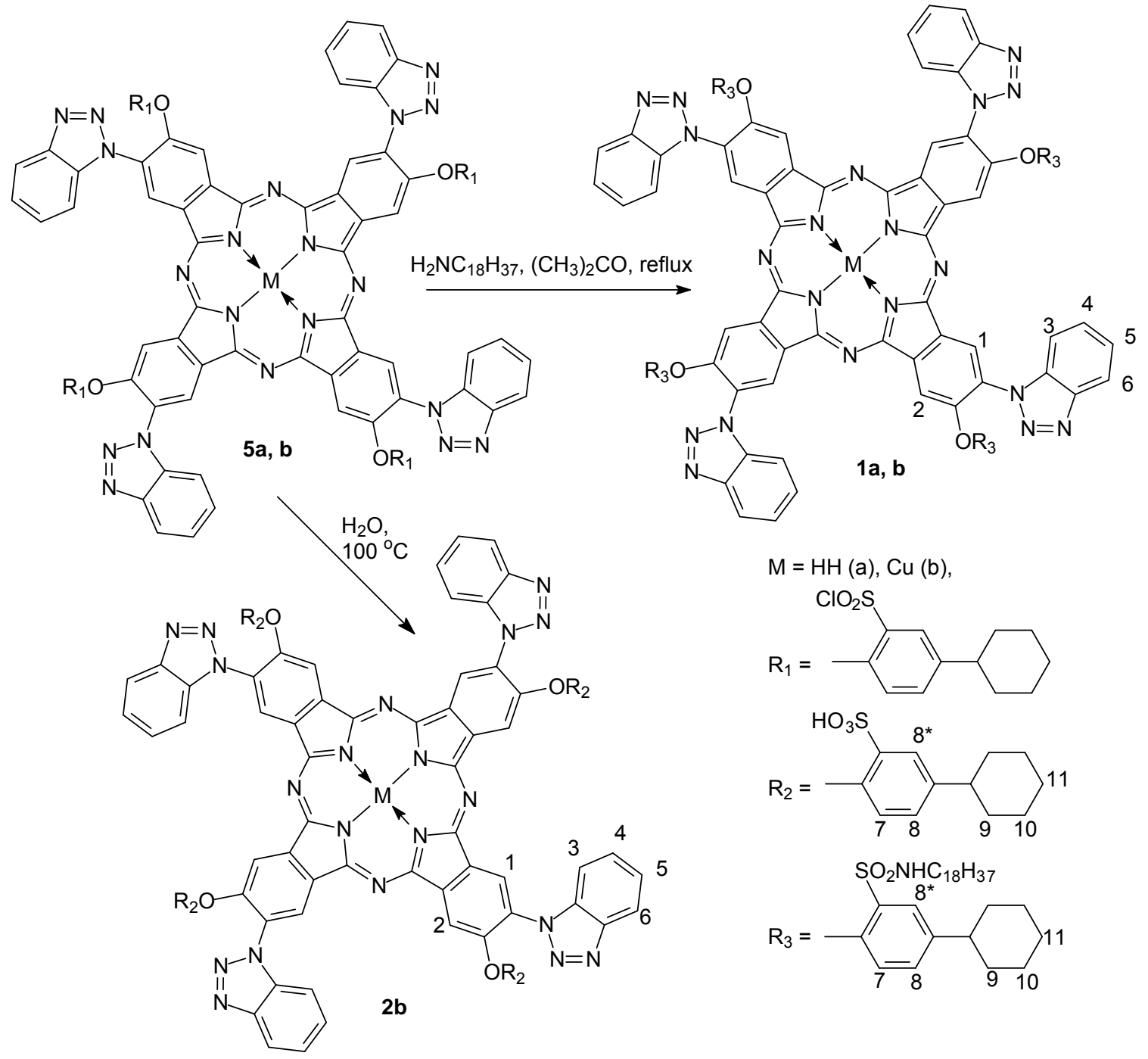

Scheme 3 
In the ${ }^{1} \mathrm{H}$ NMR spectrum of alkylsulfamoyl derivative $\mathbf{2} \mathbf{b}$ the intense signals of methylene groups belonging to octadecyl substituents were observed in strong field region at 3.2-1.2 ppm. The signal of the protons of methyl groups of alkyl chains were detected at $0.92 \mathrm{ppm}$. In the strong field region (at 2.90$3.15 \mathrm{ppm}$ ) there were signals of methylene groups of cyclohexyl substituents, which were previously found in the spectra of the starting compounds [10]. The signal of protons of the secondary amino groups of the octadecylsulfamoyl substituents was detected in lower field (at $5.40 \mathrm{ppm}$ ).

Introduction of sulfo groups into the molecule of 2,9,16,23-tetrakis(1-benzotriazolyl)-3,10,17,24-tetrakis(4-cyclohexylphenoxy)phthalocyanine 1a or its copper complex $\mathbf{1 b}$ causes the appearance in the IR spectrum of symmetric (at $1175 \mathrm{~cm}^{-1}$ ) and asymmetric (at $1330-1349 \mathrm{~cm}^{-1}$ ) vibrations characteristic of $\mathrm{S}=\mathrm{O}$ bonds and stretching vibrations of $\mathrm{C}-\mathrm{S}$ bonds (at $1088-1091 \mathrm{~cm}^{-1}$ ). In the IR spectrum of compound 1a the band specific to metal-free phthalocyanine (usually

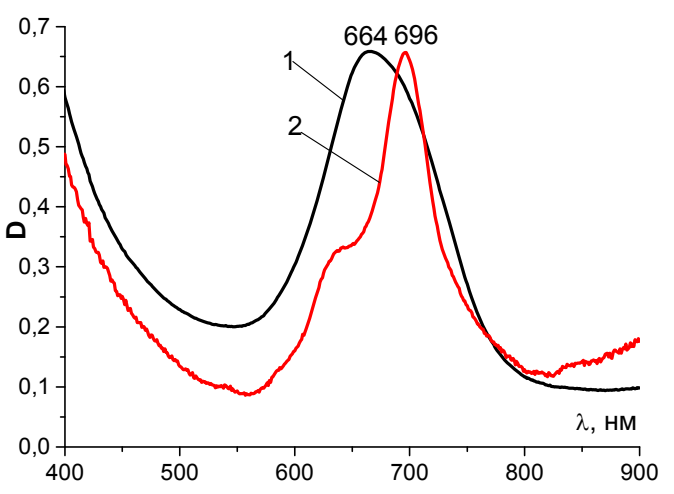

Fig. 2. Electronic absorption spectra in aqueous $\mathrm{NH}_{4} \mathrm{OH}$ $(5 \%)\left(\mathrm{C}=0.6 \cdot 10^{-5} \mathrm{~mol} / \mathrm{l}\right): 1-\mathbf{1 a}, 2-\mathbf{1 b}$ observed at $1005 \mathrm{~cm}^{-1}$ ) was shifted to the region of higher frequency $\left(1024 \mathrm{~cm}^{-1}\right)$. Introduction of alkylsulfamoyl fragments was accompanied in the IR spectrum by the appearance of stretching bands $\left(1533 \mathrm{~cm}^{-1}\right)$ and deformation oscillations $\left(1617 \mathrm{~cm}^{-1}\right)$ of the secondary amino groups.

Since sulfo groups of sulfonic acids $\mathbf{1 a}, \mathbf{b}$ were introduced into sterically closed position of phenyloxy substituent and shielded from interaction with water molecules by hydrophobic cyclohexyl fragments, both compounds were insoluble in the water, but soluble in aqueous-alkaline solutions and DMF. Octadecylsulfamoyl derivative $\mathbf{2 b}$ is highly soluble in acetone and chloroform, but low soluble in DMF.

\section{Electronic absorption spectra}

By analyzing spectra of sulfonic acids 1a,b in $5 \%$ aqueous ammonium hydroxide solution, it was found that the presence of copper atom in the coordination center of phthalocyanine molecule reduces its tendency to association (Fig. 1).

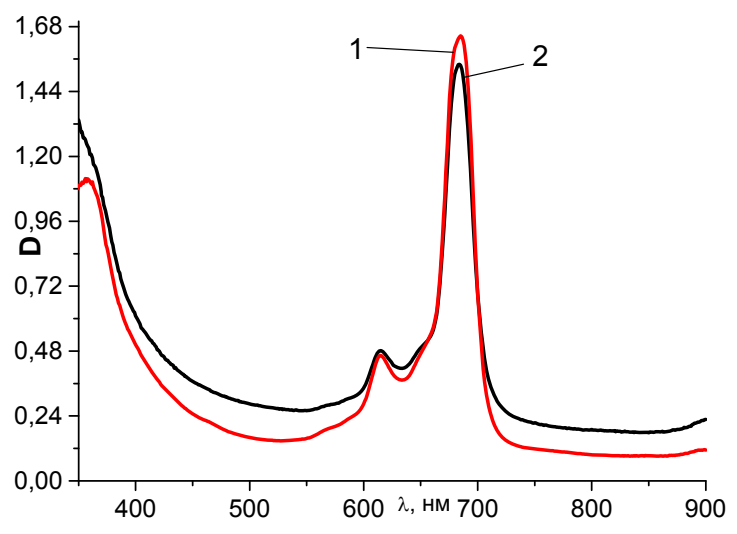

Fig. 3. Electronic absorption spectra in DMF $\left(\mathrm{C}=0.85 \cdot 10^{-5} \mathrm{~mol} / \mathrm{l}\right): 1-\mathbf{1 a}, 2-\mathbf{1 b}$

Table 1. UV-Vis spectroscopy data for compounds $1 \mathbf{a , b}, \mathbf{2 b}$ and $4 \mathbf{a}, \mathbf{b}$ in different solvents

\begin{tabular}{|c|c|c|c|c|c|c|}
\hline \multirow[t]{2}{*}{ № } & \multirow[t]{2}{*}{$\mathrm{R}$} & \multirow[t]{2}{*}{ M } & \multicolumn{4}{|c|}{ UV-Vis spectra, $\lambda_{\max }, \mathrm{nm}$} \\
\hline & & & $\mathrm{NH}_{4} \mathrm{OH}(5 \%)$ & DMF & $\mathrm{CHCl}_{3}$ & $\mathrm{H}_{2} \mathrm{SO}_{4}$ \\
\hline $\mathbf{1 a}$ & $\mathrm{HO}_{3}$ & $\mathrm{HH}$ & 664 & 694 & - & 803 \\
\hline 1b & & $\mathrm{Cu}$ & 642,697 & 692 & - & 769,791 \\
\hline 2b & $\mathrm{SO}_{2} \mathrm{NHC}_{18} \mathrm{H}_{3}$ & $\mathrm{Cu}$ & - & 684 & 684 & 767,790 \\
\hline $4 \mathbf{a}$ & & $\mathrm{HH}$ & - & 684 & 689 & 795,836 \\
\hline $4 b$ & & $\mathrm{Cu}$ & - & 685 & 675,710 & 802 \\
\hline
\end{tabular}


Considering the character of electronic absorption spectra in DMF, one can conclude that the sulfonic acids 1a,b were unassociated (Fig. 3). In the spectrum of alkylsulfamoyl copper phthalocyanine $\mathbf{2 b}$ in chloroform, a broadening of absorption bands located in the visible region, and disobedience to the Lambert-Bouguer-Beer law were observed, which indicate the association processes (Fig. 4). According to the nature of its absorption spectrum, compound $\mathbf{2 b}$ in DMF solution was in unassociated form (Fig. 4), but due to poor solubility of this phthalocyanine in DMF it was not possible to determine its extinction coefficient.

The change of organic solvent for the concentrated sulfuric acid, as expected, causes a bathochromic shift of the absorption bands in the electronic absorption spectra, but this shift is smaller in comparison with "parent" compounds $\mathbf{4 a , b}$ (Table 1 [10]). As in the case of $\mathbf{4 a , b}$, the spectral curves are diffuse.

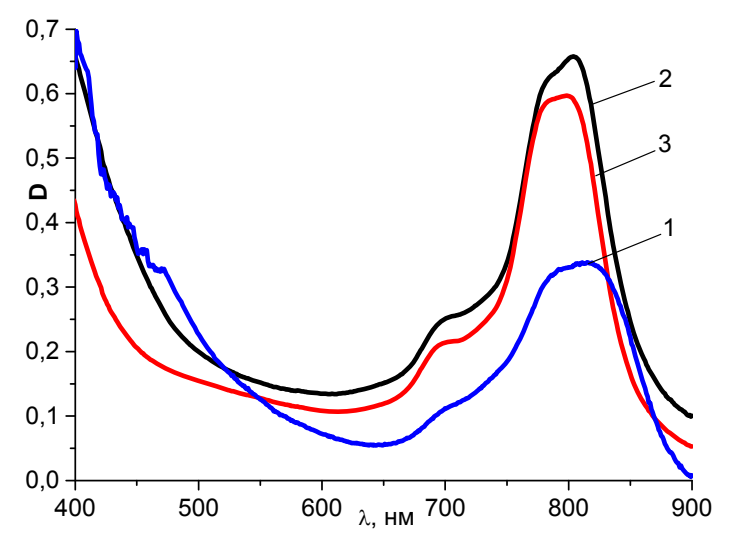

Fig. 5. Electronic absorption spectra in $\mathrm{H}_{2} \mathrm{SO}_{4}$ :

$$
1-\mathbf{4 a}, 2-\mathbf{1 a}, 3-\mathbf{1 b}
$$

Comparing the "parent" compound 4a with its sulfonic acid 1a a hypsochromic shift of Q-band at $33 \mathrm{~nm}$ was detected. Introduction of copper atom into the molecule 1a causes a hypsochromic shift of Q-band for further $12 \mathrm{~nm}$ (Fig. 5). The transition from copper phthalocyanine $\mathbf{4 b}$ to its octadecylsulfamoyl derivative $\mathbf{2 b}$ is also accompanied by a hypsochromic shift of Q-band at $14 \mathrm{~nm}$ (Fig. 6).

\section{Solubility study}

Solubility of macroheterocyclic compounds has its own specificity, which is generally determined by two factors: the strength of the crystal lattice of these compounds and solvation by solvent molecules. The

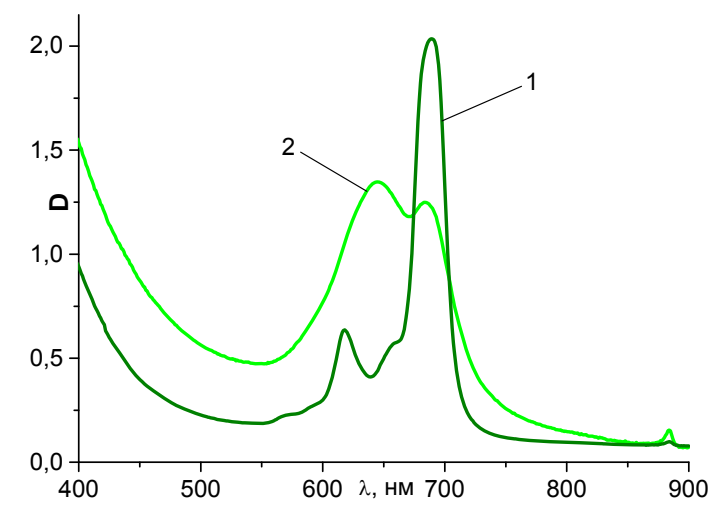

Fig. 4. Electronic absorption spectra for compound $\mathbf{2 b}$ in organic solvents $\left(\mathrm{C}=1.0 \cdot 10^{-5} \mathrm{~mol} / \mathrm{l}\right): 1-\mathrm{DMF}, 2-\mathrm{CHCl}_{3}$

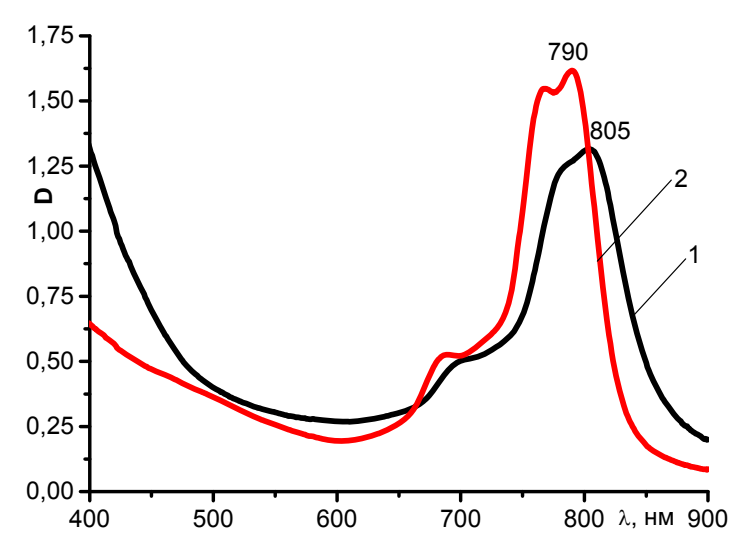

Fig. 6. Electronic absorption spectra in $\mathrm{H}_{2} \mathrm{SO}_{4}$ : $1-\mathbf{4 b}, 2-\mathbf{2 b}$

complexity and diversity of phthalocyanine structures define the specific behavior of these compounds in chemical reactions and physicochemical processes that take place in solutions [11].

It is known that the unsubstituted phthalocyanine and its complexes at normal conditions are unsoluble in either water or in organic solvents [12]. The modification of the phthalocyanine molecule by introduction of functional substituents of different nature can impart solubility in organic solvents by introducing the centers of specific solvation and loosening the molecular lattice. Changing the structure of the molecule and its effective volume should be accompanied by a change in the crystal lattice 
strength due to intermolecular interactions in crystal and, as a consequence, different inclinations of compound to undergo transition into solution. The solubility study of bifunctionally substituted phthalocyanines in various solvents is of interest. Therefore, the solubility of compounds $\mathbf{1 a}, \mathbf{b}$ and $\mathbf{4 a , b}$ in DMF and chloroform has been investigated.

The presence of bulky substituents affects the strength of the crystal lattice due to its loosening, thereby makes compounds soluble in organic solvents. Solubility of 2,9,16,23-tetrakis(1-benzotriazolyl)-3, 10,17,24-tetrakis(4-cyclohexylphenoxy)phthalocyanine $\mathbf{4 a}$ and its copper complex $\mathbf{4 b}$ as well as their sulfonic acids 1a,b in DMF at $298 \mathrm{~K}$ is $10^{-2} \mathrm{~mol} / 1$ (Table. 2).

The experimental data on solubility of compounds 4a,b in DMF and chloroform at $298 \mathrm{~K}$ show that solubility in chloroform is lower than in DMF. This fact can indirectly indicate a decrease in the strength of the molecular lattice, as well as an increased affinity of large organic molecules to DMF. This difference is due to the nature and the solvating ability of the used solvents. Thus, chloroform is weakly polar, proton-donor non-coordinating solvent, it is practically not associated with proton acceptors and gives a strong hydrogen bond. $\mathrm{AN}=23.1$, $\varepsilon=4.80$. On the other hand, DMF is dipolar solvent with a strong electron-donating function ( $\mathrm{DN}=26)$. Considering the nature in solubility changes of compounds $\mathbf{4 a}$ and $\mathbf{4 b}$ in chloroform, we may conclude that despite the presence of specific solvation centers, they are sterically shielded from chloroform molecules. Therefore the solubility of compounds $\mathbf{4 a}, \mathbf{b}$ is slightly different from solubility of similar structure copper phthalocyanine containing unsubstituted phenoxy groups [13]. Reduction of solubility in DMF in the case of sulfonic acids 1a,b in comparison with their "parent" compounds $\mathbf{4 a}$ and $\mathbf{4 b}$ was also detected.

Table 2. Solubility of compounds $1 \mathbf{a}, \mathbf{b}$ and $4 \mathbf{a}, \mathbf{b}$ in organic solvents

\begin{tabular}{|c|c|c|c|c|c|c|c|c|}
\hline \multirow{2}{*}{$\begin{array}{l}\text { Com- } \\
\text { pound }\end{array}$} & \multirow[t]{2}{*}{$\mathbf{M}$} & \multirow[t]{2}{*}{$\mathbf{R}$} & \multicolumn{3}{|c|}{$\mathrm{S} \pm 0.05\left(\mathrm{CHCl}_{3}\right)$} & \multicolumn{3}{|c|}{$\mathrm{S} \pm 0.05(\mathrm{DMF})$} \\
\hline & & & $\lambda_{\max }, \mathrm{nm},(\lg \varepsilon)$ & $\mathrm{mol} / \mathrm{l}$ & $\mathrm{g} / 1$ & $\begin{array}{l}\lambda_{\max }, \mathrm{nm}, \\
\quad(\lg \varepsilon)\end{array}$ & $\mathrm{mol} / \mathrm{l}$ & $g / 1$ \\
\hline $4 a$ & $\mathrm{HH}$ & & $688(4.92)$ & 2.1 & 3.59 & $684,(4.82)$ & 10.52 & 17.98 \\
\hline $4 \mathrm{~b}$ & $\mathrm{Cu}$ & & $692(4.92)$ & 3.1 & 4.81 & $685,(4.87)$ & 10.29 & 17.85 \\
\hline $1 \mathrm{a}$ & $\mathrm{HH}$ & & \multirow{2}{*}{\multicolumn{3}{|c|}{ insoluble }} & $694(4.78)$ & 7.71 & 15.90 \\
\hline 1b & $\mathrm{Cu}$ & & & & & $692(4.87)$ & 7.72 & 16.05 \\
\hline
\end{tabular}

S - solubility

\section{Thermogravimetry}

The thermal oxidative degradation process of metal-free phthalocyanines $\mathbf{1 a}$ and $\mathbf{4 a}$ was studied. The results are given in Table 3 .

The thermal decomposition process of compounds $1 \mathbf{a}$ and $\mathbf{4 a}$ consists of two stages. The first one occurs in the temperature range $280-360{ }^{\circ} \mathrm{C}$. According to the weight loss value observed on TG curves (27.91 \% for $\mathbf{4 a}$ and $23.35 \%$ for $\mathbf{1 a}$ ), the decomposition occurs with the participation of benzotriazolyl substituents, as it was found previously for other phthalocyanines combining on the periphery benzotriazolyl and oxyaryl groups [14]. For example for compounds $4 \mathbf{a}$ and 1a, heated up to $290{ }^{\circ} \mathrm{C}$, in the IR spectra there was no band corresponding to the stretching vibrations of $\mathrm{N}=\mathrm{N}$ bond of benzotriazolyl fragment $\left(1040-1050 \mathrm{~cm}^{-1}\right)$. At the same time, it was found that compound $\mathbf{4 a}$ retains solubility in chloroform and compound $\mathbf{1 a}$ - in aqueous alkaline solutions. That is, the mass loss at this stage can be caused by the removal of benzotriazole, but not aryloxy fragments.

Table 3. Data of thermogravimetrical study

\begin{tabular}{|c|c|c|c|}
\hline Compound & $\mathrm{R}$ & $\Delta \mathrm{T},{ }^{\circ}$ & $\mathrm{T}_{\text {exo }},{ }^{\circ} \mathrm{C}$ \\
\hline 4a & \\
\hline $1 a$ & $462-604$ & 563 \\
\hline
\end{tabular}

$\Delta \mathrm{T}$ - temperature range corresponding to the maximum weight loss of the sample, $\mathbf{T}_{\mathbf{e x o}}$ - maximum temperature of exo-effect 
Table 3 shows that introduction of sulfo groups into the molecule of 2,9,16,23-tetrakis(1-benzotriazolyl)-3,10,17,24-tetrakis(4-cyclohexylphenoxy) phthalocyanine causes a decrease in the thermal stability of the corresponding sulfo-derivative on $33^{\circ} \mathrm{C}$.

\section{Mesomorphic properties}

Phthalocyanine derivatives $\mathbf{1 b}$ and $\mathbf{2 b}$ were investigated by polarizing microscopy to study possibility to show mesomorphic properties. Previously, it was found that compounds $\mathbf{4 a}, \mathbf{b}$ form a thermotropic mesophase [15].

Table 4. Influence of donor fragment structure on mesogenity of mix-substituted phthalocyanines

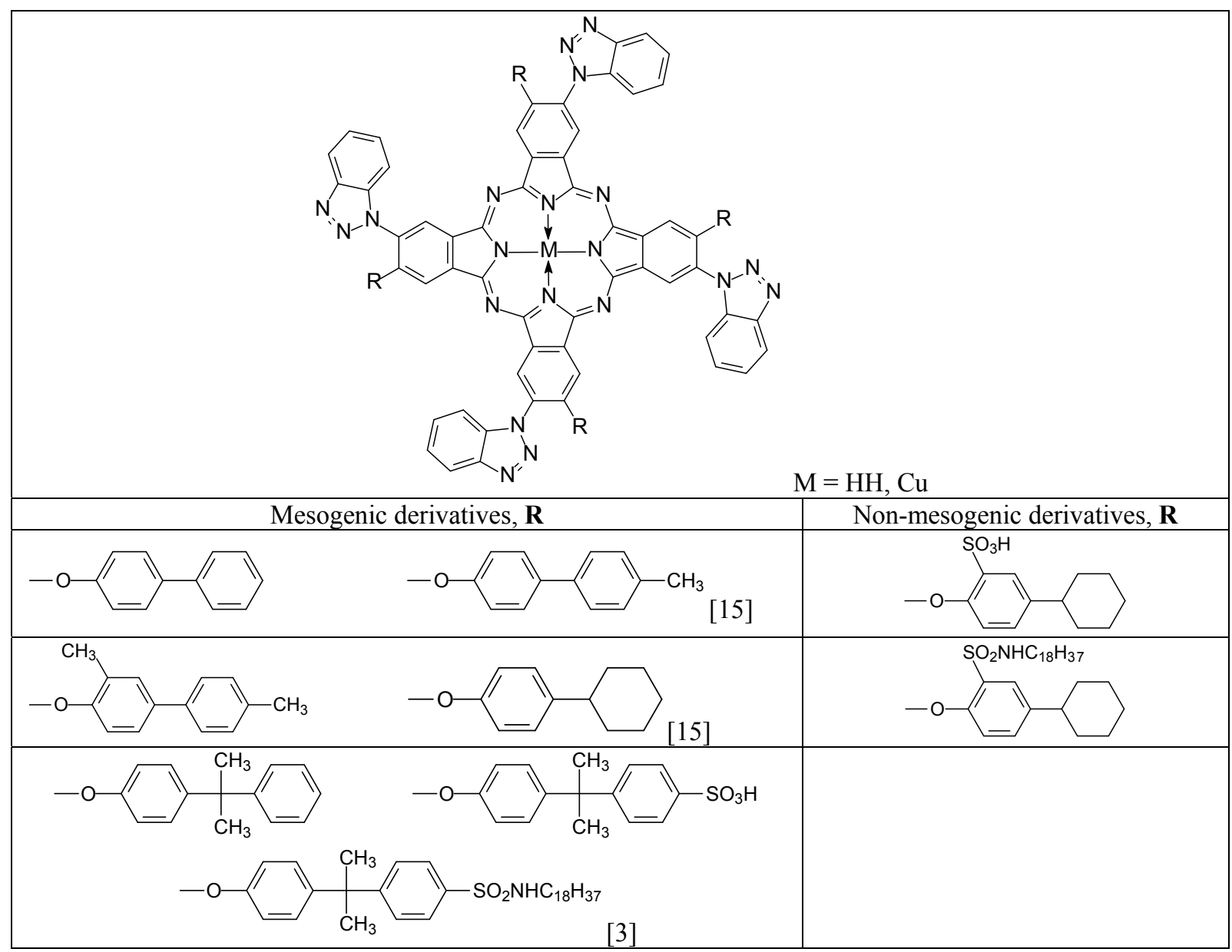

Introduction of sulfo or alkylsulfamoyl groups into donor fragments of the previously studied mixsubstituted phthalocyanines with benzotriazolyl substituents (Table 4) did not lead to the disappearance of mesomorphic properties. Moreover, in comparison with non-mesogenic homosubstituted phthalocyanine with eight benzotriazolyl substituents such substitution induced liquid crystallinity. However, we have found that the behavior of the compounds presented in this work is fundamentally different. Thus, sulfo-substituted copper phthalocyanine $\mathbf{1 b}$ melts at $200-220{ }^{\circ} \mathrm{C}$ and displays no mesomorphic properties. Compound $\mathbf{2 b}$ with octadecylsulfamoyl fragments melts at much lower temperature $-80-85^{\circ} \mathrm{C}$, while it also does not show mesomorphism. Therefore, both compounds showed no inclination to the mesophase formation.

\section{Prognosis of mesomorphism}

To explain the difference in mesomorphic behavior, molecular modeling of phthalocyanine derivatives 1-2 was performed with the help of HyperChem software using the method of molecular mechanics $(\mathrm{MM}+)$. On the basis of the modeling the molecular parameters (MP) were calculated and analyzed. MPs are the dimensionless parameters 
extracted from the structure of single molecules by comparing the calculated values with the classification series $\{1\}[3,15-19]$ :

$$
K=2-8.5 ; \quad K_{c}=1-2.6 ; \quad K_{p}=0.2-0.7 ; \quad K_{s}=0.25-1.00 ;
$$$$
M_{m}=0.2-0.8 ; M_{r}=0.15-0.80 ; K_{a r}=0.08-0.30
$$

Parameter $\boldsymbol{K}$ characterizes anisometry of a molecule as a whole. Parameters $\boldsymbol{K}_{c}$ and $\boldsymbol{K}_{p}$ characterize the central part and the periphery of molecule, respectively. Parameter $\boldsymbol{K}_{s}$ indicates the substitution degree of the central part by the peripheral substituents. Parameter $\boldsymbol{M}_{\boldsymbol{m}}$ takes into account the ratio of the central part mass and the periphery mass of the molecule. Parameter $\boldsymbol{M}_{r}$ takes into account the surrounding degree of the central part of the molecule by the peripheral substituents. Parameter $\boldsymbol{K}_{a r}$ is proposed to take into account the packing density of the peripheral substituents [15-19].

Examples of the optimized models are presented in Figure 7.

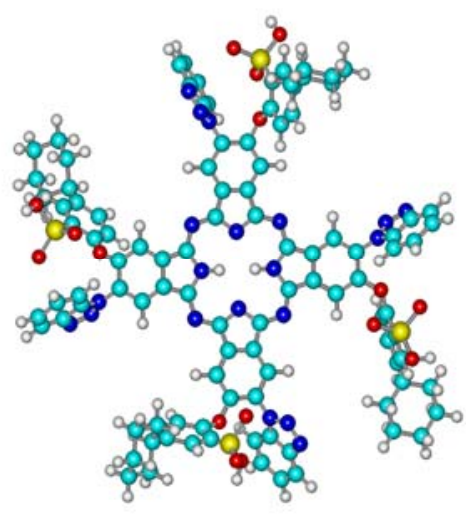

a

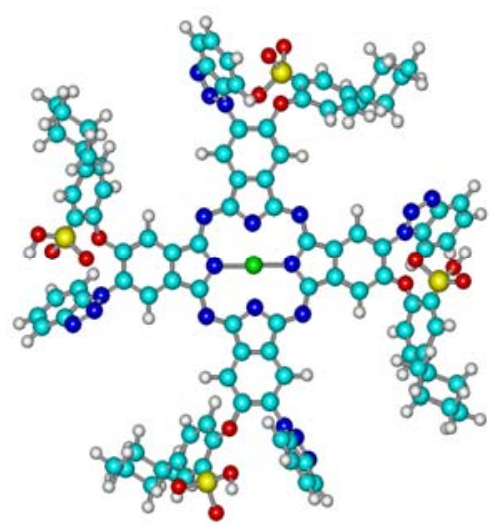

c

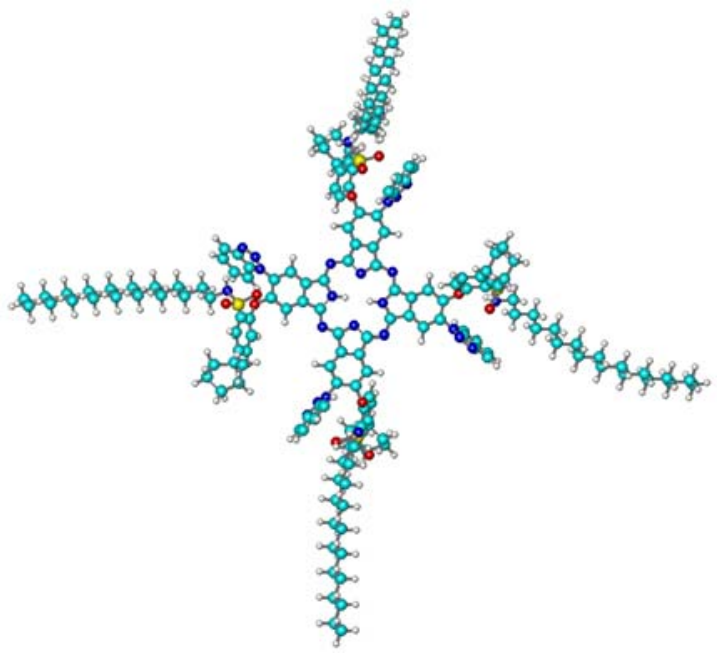

b

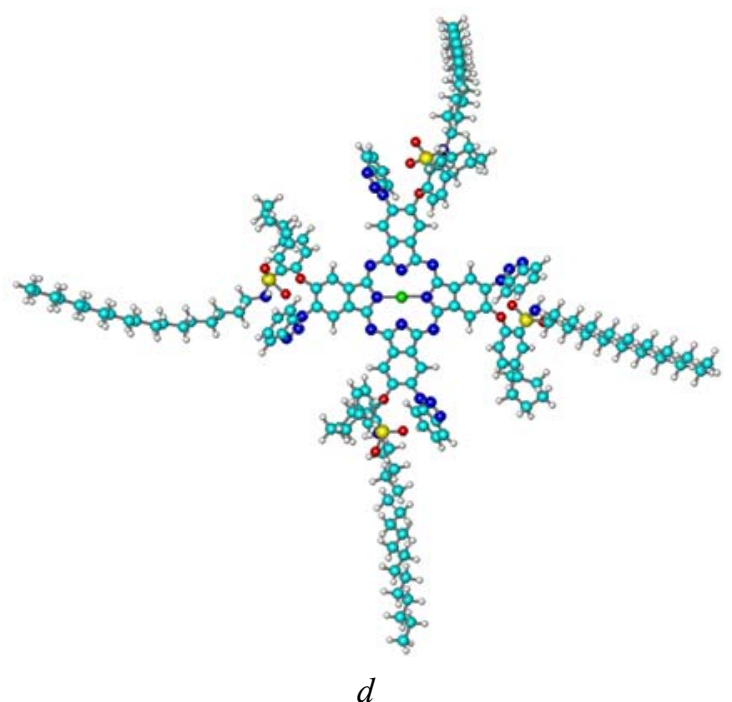

Fig. 7. Samples of optimized models of molecule of compounds $\mathbf{1 a}(a), \mathbf{2 a}(b), \mathbf{1 b}(c)$ and $\mathbf{2 b}(d)$ 
Table 5. Calculated molecular parameters (MP) and the prognosis data for phthalocyanines 1a,b and 2a,b

\begin{tabular}{|c|c|c|c|c|c|c|c|c|c|}
\hline \multirow[t]{2}{*}{ Compound } & \multirow{2}{*}{$\begin{array}{c}\mathrm{E}_{\mathrm{opt}}, \\
\mathrm{kCal} / \mathrm{mol}\end{array}$} & \multicolumn{6}{|c|}{ Molecular parameter $(M P)$} & \multirow{2}{*}{$P$} & \multirow{2}{*}{$E$} \\
\hline & & $M_{m}$ & $M_{r}$ & $K_{p}$ & $K$ & $K_{c}$ & $K_{a r}$ & & \\
\hline $1 \mathrm{a}$ & 246.79 & 0.40 & 0.20 & 0.69 & $1.73^{6}$ & 1.17 & 0.27 & - & - \\
\hline $1 \mathbf{b}$ & 283.16 & 0.44 & 0.22 & 0.69 & $1.73^{6}$ & 1.17 & 0.27 & - & - \\
\hline $2 \mathbf{a}$ & 361.60 & 0.23 & $0.12 *$ & 0.24 & $1.45^{6}$ & 1.16 & 0.12 & - & - \\
\hline $2 \mathbf{b}$ & 386.17 & 0.26 & $0.13 *$ & 0.24 & $1.37^{6}$ & 1.16 & 0.13 & - & - \\
\hline
\end{tabular}

$\mathrm{E}_{\text {opt }}-$ optimization energy, $K_{s}=0.50$ for all compounds, $P$ - prognosis of mesomorphism typical for $D M$; $E$ - result of experiment. * $-M P$ values closed to the boundary of the classification series (1). ' $-M P$ values deviated significantly from the classification series $\{1\}$. Description of $M P s-$ see in the text

The data on mesomorphism prognosis characteristic for DM showed that liquid crystalline properties for the synthesized compounds should not be expected (Table 5). In general, the negative prognosis is given for one of $M P \mathrm{~s}$, namely the $K$ parameter, which characterizes the flatness of the molecule, i.e. the ratio of the maximum length of the molecule to its thickness. Since the molecules, according to the simulation data, are quite flat, they are located close to each other, thus creating the conditions for effective interaction between their $\pi$ systems. At the same time, in order to achieve a "crystal - mesophase" phase transition the system requires more energy, i.e. transition temperature to liquid crystal state is higher than the melting point of the compound. The enhancement of intermolecular interactions at introduction of sulfo groups can explain the decrease in solubility of compounds $\mathbf{1 a}, \mathbf{b}$ in DMF, in comparison with the "parent" compounds $\mathbf{4 a}, \mathbf{b}$.

For octadecylsulfamoyl derivatives $\mathbf{2 a , b}$ the molecular parameter $K$ as well as the molecular parameter $M_{r}\left(M_{r}\right.$ takes into account the number of substituents on the periphery) locate beyond the boundaries of the classification series $\{1\}$. The value of $M_{r}$ is less than its lower boundary value in the classification series $\{1\}$ (Table 5). This indicates the presence of free volume excess in the intermolecular space around molecules that impairs the microsegregation (i.e. it prevents molecules to selforganise and form supramolecular ensembles, which are mesophase structural units).

\section{Conclusions}

New sulfo and alkylsulfamoyl derivatives of phthalocyanine combining at the periphery 1-benzo- triazolyl and cyclohexylphenoxy groups were synthesized. Elemental analysis proved that the studied phthalocyanines contain 4 sulfo or alkylsulfamoyl fragments. ${ }^{1} \mathrm{H}$ NMR spectroscopy revealed that the substitution by sulfo groups occurs in the ortho-position to the oxygen bridge of the phenoxy-substituent. The effect of introduction of sulfo- and octadecylsulfamoyl groups into aryloxy substituents on the location of long-wave absorption bands of the synthesized compounds in concentrated sulfuric acid was found. The effect is expressed in hypsochromic shift of absorption bands in comparison with the starting compounds. It was established that the introduction of sulfo groups into bi-functionally substituted phthalocyanine molecules with 1-benzotriazolyl and cyclohexylphenyl fragments leads to a decrease of the solubility of the synthesised compounds, decrease of the maximum temperature of the mass loss and the inability of the compounds to form a mesophase. All mentioned above can be explained by strengthening of intermolecular interactions between central parts of the molecules. The introduction of octadecylsulfamoyl substituents also contributes to the absence of mesomorphism, which, in our opinion, can be connected with sterical hindrance of liquid crystalline molecular packing.

The performed work for the first time revealed that introduction of bulky sulfo or alkylsulfamoyl fragments into ortho-position with respect to the oxygen atom of aryloxy group excludes manifestation of liquid crystalline properties. While substitution by the same fragments in para-position leads to formation of mesophase. It was shown that the presence of donor and acceptor fragments in mix-substituted phthalocyanines is important [4] but not determining factor for mesophase formation of disc-like molecules. 
The work was supported by the Program of the Ministry of Education and Science of the Russian Federation in the framework of the state task for Ivanovo State University of Chemistry and Technology (Grant № 4.1929.2017/ПЧ) and for Ivanovo State University to carry out research work in 2017-2019 (Grant № 16.1037.2017/חЧ) and partially supported by the RFBR (Grant № 16-03-00883a).

\section{References}

1. Usol'tseva N.V., Akopova O.B., Bykova V.V., Smirnova A.I., Pikin S.A. Liquid crystals: discotic mesogens / ed. by N.V. Usol'tseva, Ivanovo: IvSU, 2004, 546 p. (in Russ.).

2. Znoiko S.A., Krivova A.I., Shaposhnikov G.P., Anan'eva G.V., Usol'tseva N.V. Synthesis and Mesomorphism of Sulfonic Acids of Tetrakis-4-(1Benzotriazolyl)Tetrakis-5-[1(2)-Naphtoxy]Phthalocyanines. Liq. Cryst. and their Appl. 2012, 4 (42), 62-70 (in Russ.).

3. Znoiko S.A., Akopova O.B., Bumbina N.V., Maizlish V.E., Shaposhnikov G.P. Synthesis and properties of sulfo and alkylsulfamoyl substituted $\mathrm{Cu}^{\mathrm{II}}$ and $\mathrm{Ni}^{\mathrm{II}}$ phthalocyanines bearing 1-benzotriazolyl and 4-(1methyl-1-phenylethyl)phenoxy groups. Macroheterocycles, 2014, 7 (3), 287-295.

4. Usol'tseva N.V., Smirnova A.I., Kazak A.V., Sotsky V.V., Luk'ianov I.Yu., Galanin N.E., Shaposhnikov G.P. Nanostructural materials on the basis of mesogenic mixsubstituted phthalocyanines. In Organic and hybrid nanomaterials: obtaining and application prospects: monograph / ed. by Razumov V.F. and Kluev M.V., Ivanovo, Ivanovo State University, 2015, Ch. 13, 557619. (in Russ.).

5. Usol'tseva N.V., Kazak A.V., Luk'yanov I.Yu., Sotsky V.V., Smirnova A.I., Yudin S.G., Shaposhnikov G.P., Galanin N.E. Influence of molecular structure peculiarities of phthalocyanine derivatives on their supramolecular organization and properties in the bulk and thin films. Phase Transitions, 2014, 87 (8), 801813. DOI: $10.1080 / 01411594.2014 .893343$.

6. Galanin N.E., Shaposhnikov G.P., Smirnova A.I., Kazak A.V., Usol'tseva N.V. Synthesis, spectral and mesomorphic properties of mix-substituted phthalocyanines based on 3,6-dioctyloxyphthalonitrile and 4,5-dichlorophthalonitrile, and their holmium complexes. Liq. Cryst. and their Appl., 2014, 14 (4), 74-84 (in Russ.)

7. Usol'tseva N.V., Smirnova A.I., Kazak A.V., Kovaleva M.I., Galanin N.E., Shaposhnikov G.P., Bodnarchuk V.V., Yablonskii S.V. Optical, mesomorphic and photoelectric properties of the mixsubstituted phthalocyanine ligands and their metal complexes of the $\mathrm{A}_{3} \mathrm{~B}$ type. Liq. Cryst. and their Appl.,
2015, 15 (4), 56-71 (in Russ.) DOI: 10.18083/LCAppl.2015.4.56.

8. Berezina G.R., Vorobev Yu.G. Solubility of macroheterocyclic compounds based on 5,7-diimino-2,5,6,7tetrahydro-1h-cyclopenta[cd]phenalene in individual solvents. Russ. J. Phys. Chem. A, 2005, 79 (4), 579-582.

9. Akopova O.B., Akopov D.A. Computer program «CMP ChemCard» № 2012610165, 10.01.2012 (in Russ.)

10. Znoiko S.A., Akopova O.B., Bumbina N.V., Usol'tseva N.V., Maizlish V.E., Shaposhnikov G.P., Abramov I.G. Nucleophilic substitution in 4-bromo-5-nitrophthalodinitrile: XI. Preparation, properties, and prediction of mesomorphism in mixed-substituted phthalocyanines containing aryloxy and benzotriazole fragments. Russ. $J$. Gen. Chem. 2014, 84, 708-714.

11. Krestov G.A., Berezin B.D. Basic Concepts of Modern Chemistry. Leningrad: Chemistry, 1983, 102 p. (in Russ.)

12. Berezin B.D. Coordination Compounds of Porphyrins and Phthalocyanines. Moscow: Nauka, 1981, 300 p.

13. Berezina G.R., Znoiyko S.A., Maiyzlish V.E. Solubility of benzotryazolyl-substituted phthalocyanines in organic solvents. Izv. Vuzov. Khim. I Khim. Tekh., 2012, 55 (5), 27-30 (in Russ.).

14. Znoiko S.A., Maizlish V.E., Shaposhnikov G.P., Lebedeva N.Sh., Mal'kova E.A. Stability of benzotriazolyl-substituted phthalocyanines with respect to thermal oxidative decomposition. Russ. J. Phys. Chem. A, 2013, 87 (3), 352-356.

15. Znoiko S.A., Maizlish V.E., Shaposhnikov G.P., Bykova V.V., Usol'tseva N.V. Mesomorphism of octasubstituted phthalocyanines, combined benzotryazolyl and aryloxy-groups on periphery. Liq. Cryst. and their Appl., 2011, 4, 69-79 (in Russ.).

16. Zemtsova O.V., Akopova O.B., Usol'tseva N.V. Prediction of nematic mesomorphism. Compounds with disclike molecules. J. Structural Chemistry, 2002, 43, 1053-1057.

17. Akopova O.B., Gruzdev M.S., Kurbatova E.V. Synthesis and study of heptasubstituted triphenylenes with chiral fragments and predictable type of mesomorphism. Russ. J. Gen. Chem., 2010, 80, 268-274.

18. Bumbina N.V., Luk'yanov I.Yu., Akopova O.B., Usol'tseva N.V. Comparative analysis of mesomorphism prognosis for porphyrin and phthalocyanine derivatives by two different methods. Liq. Cryst. and their Appl., 2012, 12 (3), 31-36 (in Russ.)].

19. Bumbina N.V., Akopova O.B., Usol'tseva N.V., Znoiko S.A., Maizlish V.E., Shaposhnikov G.P. Prognosis of Mesomorphism for Heterosubstituted Metal-Free Phthalocyanines. Liq. Cryst. and their Appl., 2013, 13 (4), 45-52 (in Russ.)

Поступила в редакиию 23.01.2017 г. Received 23 January 2017 